\title{
Uji Aktivitas Sel Kanker dengan menggunakan senyawa Flavonoid dari Lengkuas (Alpinia Galanga)
}

\author{
I. A. K. Pramushinta ${ }^{1}$ dan P. S. Ajiningrum ${ }^{2}$ \\ Fakultas Matematika dan Ilmu Pengetahuan Alam \\ Universitas PGRI Adi Buana Surabaya
}

\begin{abstract}
ABSTRAK
Tanaman ini sudah cukup dikenal masyarakat Indonesia dan biasanya digunakan sebagai bumbu campuran pada masakan. Bagian tanaman ini yang biasa digunakan adalah rimpangnya. Rimpang lengkuas ini bisa digunakan sebagai obat tradisional untuk diare, disentri. Pada rimpang lengkuas terdapat senyawa-senyawa flavonoid, glikosida dan diarilheptanoids. Kerangka flavonoid terdiri atas satu cincin aromatik A, satu cincin aromatik B, dan cincin tengah berupa heterosiklik yang mengandung oksigen dan bentuk teroksidasi cincin ini dijadikan dasar pembagian flavonoid ke dalam sub-sub kelompoknya. Penggunaan sel murin leukemia P388 dapat menghambat pertumbuhan sel kanker, karena pada gugus hidroksil $(-\mathrm{OH})$, gugus amida (-CONH) dan gugus dilakton merupakan gugus yang menunjukkan aktivitas menghambat pertumbuhan bakteri dan sel kanker. Ekstraksi senyawa metabolit sekunder dilakukan melalui tahapan ekstraksi dengan methanol kemudian dilanjutkan dengan uji skrining senyawa dan uji antikanker. Analisis ekstrak senyawa rimpang lengkuas dengan perbandingan 1:3 hasil lebih jernih dan baik, analisis uji skrining serbuk rimpang lengkuas didapatkan hasil positif adanya senyawa flavonoid pada uji Bate Smith \& Mertcalf dan Uji Wilstater Sianidin, penghambatan sel kanker leukimia P388 $50 \%$ dari ekstrak metanol lengkuas $16,76 \mu \mathrm{g} / \mathrm{mL}$
\end{abstract}

Kata kunci: Lengkuas; anti kanker

\section{PENDAHULUAN}

Indonesia merupakan negara yang terkenal dengan keanekaragaman tumbuhan terutama hasil pertanian dan rempah-rempahnya. Hal ini didukung oleh keadaan geografis Indonesia yang mempunyai iklim tropis dengan curah hujan yang tinggi. Sumber daya alam yang dimiliki telah memberikan manfaat yang tinggi dalam kehidupan sehari-hari. Disamping sebagai bahan makanan dan bahan bangunan, juga dimanfaatkan sebagai bahan obat-obatan tradisional. Sejak zaman dahulu masyarakat Indonesia sudah banyak menggunakan tumbuhan yang berkhasiat sebagai obat. Hal ini dilakukan sebelum masyarakat mengenal obat-obatan modern yang dibuat dari bahan kimia sintetik.

Salah satu tanaman yang digunakan sebagai obat tradisional adalah lengkuas (Alpinia galanga L). Tanaman ini sudah cukup dikenal masyarakat Indonesia dan umumnya digunakan sebagai bumbu campuran pada masakan. Bagian tanaman ini yang biasa digunakan adalah rimpangnya. Rimpang lengkuas ini bisa digunakan sebagai obat tradisional untuk diare, disentri dan lain-lain (Parwata, 2008). Pada rimpang lengkuas terdapat senyawa-senyawa flavonoid, glikosida dan diarilheptanoids. Pada penelitian sebelumnya tiga senyawa golongan flavonoid telah berhasil diisolasi dari rimpang lengkuas (Alpinia galanga $\mathrm{L}$ ) yaitu 3,5,7-trihydroksiflavon (galangin), 3,5,7trihydroksi-4'-metoksiflavon

(kaempferide) dan 5,7-dihidroksi-4'metoksi-3-O- $\beta$-d-glukopiranosidaflavon (kaempferide-3-O- $\beta$-D-glukosida).

Senyawa - senyawa tersebut diketahui mempunyai bioaktivitas sebagai antioksidan (Samart, 2007).

Kerangka flavonoid terdiri atas satu cincin aromatik A, satu cincin aromatik B, dan cincin tengah berupa heterosiklik yang mengandung oksigen dan bentuk teroksidasi cincin ini dijadikan dasar pembagian flavonoid ke dalam sub-sub kelompoknya (Hess, $t \mathrm{t}$ ). Sistem penomoran 
digunakan untuk membedakan posisi karbon di sekitar molekulnya (Rega A., 2010). Flavonoid berperan sebagai antioksidan dengan cara mendonasikan atom hidrogennya atau melalui kemampuannya mengkelat logam, berada dalam bentuk glukosida (mengandung rantai samping glukosa) atau dalam bentuk bebas yang disebut aglikon (Rega A., 2010).

\section{METODE PENELITIAN Persiapan Bahan Penelitian}

Rimpang lengkuas dicuci bersih menggunakan akuades, dipotong kecilkecil, dikeringkan, dijemur dan dihaluskan dengan mesin giling sampai berbentuk serbuk halus.

\section{Ekstraksi Senyawa}

Serbuk halus dari rimpang lengkuas dimaserasi dengan $1 \mathrm{~L}$ metanol selama 3X24 jam kemudian disaring dengan menggunakan kertas saring Whattman untuk memisahkan antara larutan dan filtrat. Untuk analisis tersebut dengan menggunakan perbandingan $1: 1 ; 1: 2 ; 1$ : 3. Air rendaman yang diambil untuk analisis uji selanjutnya.

\section{Uji Skrining Senyawa Flavonoid}

Uji skrining senyawa flavonoid diambil $3 \mathrm{~mL}$ sampel diuapkan, dicuci dengan larutan n-heksana sampai jernih. Residu dilarutkan dalam $20 \mathrm{~mL}$ metanol kemudian disaring menggunakan kertas saring Whattman. Filtrat tersebut dibagi menjadi 4 bagian A, B, C. Pada filtrat A sebagai blangko, filtrat B ditambahkan 0,5 $\mathrm{mL} \mathrm{HCl}$ pekat yang kemudian dipanaskan pada penangas air (Uji Bate Smith \& Mertclf), filtrat $\mathrm{C}$ ditambahkan $0,5 \mathrm{~mL} \mathrm{HCl}$ dan logam $\mathrm{Mg}$ yang kemudian diamati adanya perubahan warna yang terjadi (Metode Willstater sianidin). Dengan munculnya warna merah sampai jingga diberikan oleh senyawa flavonoid, sedang warna merah diberikan oleh flavonol atau flavonon. Filtrat D digunakan untuk uji Kromatografi Lapis Tipis (KLT).

\section{Uji Kromatografi Lapis Tipis (KLT)}

Uji KLT dari hasil pada uji skrining flavonoid pada filtrat $\mathrm{C}$ ditotolkan pada plat silika gel $\mathrm{G}_{60}$. Kemudian dielusi dengan perbandingan larutan butanol : asam asetat : air = 3:1: 1 setelah itu dikeringkan dan diamati pada cahaya sinar tampak Spektrofotometer UV-Vis dengan UV 254 $\mathrm{nm}$ dan $366 \mathrm{~nm}$. Plat silika gel kemudian disemprot dengan larutan amonia, dikeringkan dan diamati ulang pada cahaya sinar tampak dengan UV $254 \mathrm{~nm}$ dan 366 nm.

\section{Uji Aktivitas Anti kanker}

Uji antikanker dapat dilakukan dengan menggunakan sel murin leukemia P388. Pengkulturan sel dilakukan dalam keadaan steril. Sel murin leukemia P388 dipelihara dalam botol kultur $25 \mathrm{~cm}^{2}$, medium pemeliharaan dalam botol kultur diganti setiap 2 hari dan subkultur dilakukan ketika kultur sel telah memenuhi $80 \%$ substrat, kemudian medium pemeliharaan dibuang selanjutnya sel dicuci dengan 1,5 mL FBS (Fetal Bovine Serum) replikasi 3 kali. Setelah itu sel dibilas dengan 1,5 mL EDTA 0,02\% kemudian diberikan $1,5 \mathrm{~mL}$ tripsin $0,25 \%$ selanjutnya sel diinkubasi pada suhu $37{ }^{\circ} \mathrm{C}$ selama 2 menit. Selanjutnya medium dasar yang mengandung 50\% FBS (Fetal Bovine Serum) ditambahkan 1,5 mL. Suspensi sel tersebut dipindahkan ke dalam tabung falcon $15 \mathrm{~mL}$ kemudian suspensi sel di sentrifugasi dengan kecepatan 1000 rpm selama 5 menit sehingga didapatkan pellet sel. Medium pemeliharaan sebanyak $3 \mathrm{~mL}$ ditambahkan ke dalam pellet sel disuspensikan hingga homogen.

Ekstrak metanol kering sebanyak 1 mg ditambahkan DMSO (Dimethyl sulfoxide) sampai larut sebagai stok larutan ekstrak untuk membuat variasi konsentrasi. Kemudian dibuat variasi konsentrasi ekstrak mulai dari $0,1 \mu \mathrm{g} / \mathrm{mL} ; 0,3 \mu \mathrm{g} / \mathrm{mL}$; $1 \mu \mathrm{g} / \mathrm{mL} ; 3 \mu \mathrm{g} / \mathrm{mL} ; 10 \mu \mathrm{g} / \mathrm{mL} ; 30 \mu \mathrm{g} / \mathrm{mL}$ 
; $100 \mu \mathrm{g} / \mathrm{mL}$. Masing-masing ekstrak tersebut dimasukkan ke kultur sel murin leukemia P388. Sel yang telah diberi ekstrak dipelihara pada medium dasar yang mengandung $2 \%$ FBS dan diinkubasi selama 24 jam agar sel dapat melekat dengan substrat.

Aktifitas pertumbuhan sel setelah melakukan setelah perlakuan diukur dengan pemberian larutan MTT (3-(4,5dimetiltiazol-2-il)-2,5-difeniltertrazolium bromid). Medium dibuang dan diberi 200 $\mu \mathrm{l}$ medium dasar yang mengandung $2 \%$ FBS ( Fetal Bovine Serum) dan $50 \mu 1$ larutan MTT, sel diberi MTT untuk mengukur efek sitotoksik sampel dan sel diinkubasi selama 4 jam pada suhu $37{ }^{0} \mathrm{C}$ dengan kondisi gelap. Kemudian medium dibuang dan diberi $200 \mu 1 \mathrm{DMSO}$ dan $25 \mu 1$ buffer glisin.

\section{HASIL PENELITIAN}

Ekstraksi maserasi dengan berbagai perbandingan konsentrasi maka hasil yang paling baik yaitu pada perbandingan konsentrasi 1:3 yaitu 1 gram serbuk lengkuas dengan $3 \mathrm{~L}$ larutan metanol. Sedangkan pada perbandingan 1:1 dan 1:2 warna rendaman maserasi berwarna gelap dan keruh sehingga apabila dilakukan uji analisis selanjutnya akan mendapatkan hasil yang kurang baik.
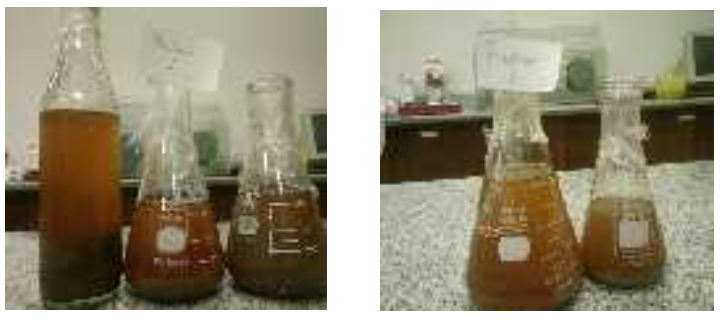

Analisis skrining ekstrak metanol rimpang lengkuas disajikan pada Tabel berikut :

\begin{tabular}{|c|c|c|c|}
\hline $\begin{array}{c}\text { Kandungan } \\
\text { Kimia }\end{array}$ & $\begin{array}{c}\text { Metode } \\
\text { Pengujian }\end{array}$ & Hasil & Keterangan \\
\hline Flavonoid & $\begin{array}{c}\text { Uji Bate Smith } \\
\& \text { Mertcalf }\end{array}$ & Orange & + \\
\cline { 2 - 4 } & $\begin{array}{c}\text { Uji Wilstater } \\
\text { Sianidin }\end{array}$ & Merah & + \\
\hline
\end{tabular}

Pelarut yang digunakan pada uji kromatografi lapis tipis (KLT) flavonoid adalah butanol : asam asetat : air dengan perbandingan $3: 1: 1$ disajikan pada Tabel berikut :

\begin{tabular}{|c|c|c|c|c|c|}
\hline $\begin{array}{c}\text { Kandungan } \\
\text { Kimia }\end{array}$ & Rf & $\begin{array}{c}\text { Sinar } \\
\text { Tampak }\end{array}$ & $\begin{array}{c}\text { UV } \\
254 \\
\text { nm }\end{array}$ & $\begin{array}{c}\text { UV } \\
366 \\
\text { nm }\end{array}$ & Ket \\
\hline Flavonoid & $\mathbf{0 , 9 2}$ & $\begin{array}{c}\text { Kuning } \\
\text { Muda }\end{array}$ & - & Biru & + \\
\cline { 2 - 6 } & $\mathbf{0 , 5 4}$ & $\begin{array}{c}\text { Kuning } \\
\text { Muda }\end{array}$ & - & Biru & + \\
\hline
\end{tabular}

Hasil analisis uji sel kanker

\begin{tabular}{|c|c|c|c|c|c|c|}
\hline \multirow{2}{*}{$\begin{array}{c}\text { Jenis } \\
\text { Ekstr } \\
\text { ak }\end{array}$} & \multirow{2}{*}{$\begin{array}{c}\text { Konsen } \\
\text { trasi } \\
\mu \mathrm{g} / \mathrm{mL}\end{array}$} & \multicolumn{3}{|c|}{ Replikasi } & \multirow{2}{*}{$\begin{array}{c}\text { Rat } \\
\text { a- } \\
\text { rat } \\
\text { a }\end{array}$} & \multirow{2}{*}{$\begin{array}{c}\mathrm{IC}_{\mathbf{5 0}} \\
\boldsymbol{\mu g} / \\
\mathrm{mL}\end{array}$} \\
\hline & & 1 & 2 & 3 & & \\
\hline \multirow[t]{7}{*}{$\begin{array}{l}\text { Leng } \\
\text { kuas }\end{array}$} & 100 & $\begin{array}{c}- \\
0,000 \\
33\end{array}$ & $\begin{array}{c}- \\
0,001 \\
33\end{array}$ & $\begin{array}{c}- \\
0,000 \\
33\end{array}$ & $\begin{array}{c}- \\
0,00 \\
06\end{array}$ & \multirow[t]{7}{*}{$\begin{array}{c}16,7 \\
6\end{array}$} \\
\hline & 30 & $\begin{array}{c}0,000 \\
667\end{array}$ & $\begin{array}{c}- \\
0,001 \\
33 \\
\end{array}$ & $\begin{array}{c}- \\
0,001 \\
33 \\
\end{array}$ & $\begin{array}{c}- \\
0,00 \\
06\end{array}$ & \\
\hline & 10 & $\begin{array}{c}0,209 \\
667 \\
\end{array}$ & $\begin{array}{c}0,179 \\
667 \\
\end{array}$ & $\begin{array}{c}0,168 \\
667 \\
\end{array}$ & $\begin{array}{c}0,18 \\
6 \\
\end{array}$ & \\
\hline & 3 & $\begin{array}{c}0,190 \\
667\end{array}$ & $\begin{array}{c}0,179 \\
667\end{array}$ & $\begin{array}{c}0,163 \\
667\end{array}$ & $\begin{array}{c}0,17 \\
8\end{array}$ & \\
\hline & 1 & $\begin{array}{c}0,153 \\
667 \\
\end{array}$ & $\begin{array}{c}0,164 \\
667 \\
\end{array}$ & $\begin{array}{c}0,157 \\
667 \\
\end{array}$ & $\begin{array}{c}0,15 \\
8 \\
\end{array}$ & \\
\hline & 0,3 & $\begin{array}{c}0,045 \\
667 \\
\end{array}$ & $\begin{array}{c}0,170 \\
667 \\
\end{array}$ & $\begin{array}{c}0,171 \\
667 \\
\end{array}$ & $\begin{array}{c}0,12 \\
9 \\
\end{array}$ & \\
\hline & 0,1 & $\begin{array}{c}0,201 \\
667\end{array}$ & $\begin{array}{c}0,081 \\
667\end{array}$ & $\begin{array}{c}0,165 \\
667\end{array}$ & $\begin{array}{c}0,14 \\
9\end{array}$ & \\
\hline
\end{tabular}




\section{PEMBAHASAN}

Hasil ekstraksi maserasi dengan berbagai perbandingan konsentrasi maka hasil yang paling baik yaitu pada perbandingan konsentrasi 1:3 yaitu 1 gram serbuk lengkuas dengan 3 L larutan metanol. Sedangkan pada perbandingan 1:1 dan 1:2 warna rendaman maserasi berwarna gelap dan keruh sehingga apabila dilakukan uji analisis selanjutnya akan mendapatkan hasil yang kurang baik.

Analisis yang dilakukan setelah melakukan ekstraksi maserasi dengan menggunakan pelarut metanol dan serbuk lengkuas adalah analisis skrining fitokimia. Analisis skrining fitokimia menggunakan pelarut n-heksana, adapun penggunakan pelarut tersebut dikarenakan pelarut bersifat polar sehingga dapat berinterasksi dengan sampel yang digunakan berdasarkan prinsip "like dissolve like"

Dari hasil uji kandungan kimia fitokimia dengan uji Wilstater Sianidin pada umumnya digunakan untuk mendeteksi senyawa yang mempunyai inti benzopyron, warna orange yang terbentuk pada Uji Bate Smith \& Mertcalf dan warna merah pada Uji Wilstater Sianidin timbul warna merah disebabkan karena terbentuknyaa garam flavilium dengan timbulnya warna tersebut maka positif adanya kandungan senyawa flavonoid.

Analisis kromatografi lapis tipis (KLT) dilakukan untuk menegaskan hasil yang didapatkan dari analisis skrining fitokimia. Uji kromatografi lapis tipis (KLT) dapat dilakukan untuk golongangolongan senyawa yang dapat menunjukkan hasil positif pada skrining fitokimia. Adapun pelarut yang digunakan pada uji kromatografi lapis tipis (KLT) flavonoid adalah butanol : asam asetat : air dengan perbandingan $3: 1$ : 1 . Setelah disemprot dengan menggunakan amonia maka timbul noda Rf 0,92 dan 0,54 yang menimbulkan warna kuning muda setelah disemprot dengan amonia pada pengamatan dengan sinar tampak dan berwarna biru pada UV $366 \mathrm{~nm}$ menegaskan adanya kandungan flavonoid pada ekstrak metanol pada lengkuas, sedangkan sinar tampak pada UV $254 \mathrm{~nm}$ tidak menimbulkan warna.Hasil uji kromatografi lapis tipis (KLT) menegaskan bahwa sampel ekstrak metanol lengkuas mengandung flavonoid didalamnya.

Analisis uji sitotoksik pada peelitian ini bermanfaat untuk mengetahui efek sitotoksik dan potensi antikanker dari ekstrak metanol lengkuas terhadap sel kanker Leukimia P388 secara invitro. Hasil pengujian analisis uji antikanker ekstrak metanol lengkuas ditentukan dengan menghitung nilai $\mathrm{IC}_{50}$ yaitu nilai konsentrasi yang dapat menekan pertumbuhan $50 \%$ populasi sel Leukimia P388. Data hasil uji MTT pada tersebut digunakan untuk menentukan OriginLab 9.0 kemudian hasil perhitungan diperoleh nilai $\mathrm{IC}_{50}$ ekstrak metanol lengkuas. Hasil uji sitotoksisitas dan nilai IC $_{50}$ ekstrak metanol lengkuas terhadap sel leukimia P388.

Hasil analisis memperlihatkan bahwa ekstrak metanol pada lengkuas terhadap sel kanker leukimia P388 mempunyai nilai konsentrasi hambatan $16,76 \mu \mathrm{g} / \mathrm{mL}$ sehingga dapat dikatakan bahwa lengkuas tergolong salah satu ekstrak yang sangat aktif hal tersebut dikarenakan kemampuan menghambat pertumbuhan sel kanker leukimia P388 sebanyak $50 \%$ terjadi pada konsentrasi ekstrak yang sangat rendah.

\section{KESIMPULAN}

Berdasarkan penelitian yang telah diakukan maka dapat ditarik kesimpulan sebagai berikut :

1. Analisis ekstrak senyawa rimpang lengkuas dengan perbandingan 1:3 hasil lebih jernih dan baik.

2. Analisis uji skrining serbuk rimpang lengkuas didapatkan hasil positif adanya senyawa flavonoid pada uji Bate Smith \& Mertcalf dan Uji Wilstater Sianidin. 
3. Penghambatan sel kanker leukimia P388 50\% dari ekstrak metanol lengkuas $16,76 \mu \mathrm{g} / \mathrm{mL}$.

\section{DAFTAR PUSTAKA}

Adom, Kafui Kwami and Rui Hai Liu, 2002, Antioksidant Activity of Grains. J. Agric. Food. Chem. (50): 6182-6187

Agoes.G., 2007, Teknologi Bahan Alam, ITB Press Bandung.

Cushnie, T.P.T., Lamb, A.J., 2011, Recent advances in understanding the antibacterial properties of flavonoids. International Journal of Antimicrobial Agents, 38(2), 99107.

Deinstrop, Elke, 2007, Applied ThinLayer Chromatography. 2nd ed. Weinheim: Wiley-VCA hal. 1-2.

Hanafi, M., et al, 2010, Sintesis dan uji sitotoksik in vitro senyawa 2Hidroksinikotinil Oktilamida terhadap sel kanker murin P388. Institut Pertanian Bogor, Bogor.

Haris, M. 2011, Penentuan Kadar Flavanoid Total Dan Aktivitas Antioksidan Dari Daun Dewa (Gynura pseudochina [Lour] DC) Dengan spektrofotometer $U V$ Visibel. Skripsi. Fakultas Farmasi. Universitas Anadalas. Padang.
Kurniasari, I. 2006, Metode Cepat Penentuan Flavanoid Total Meniran (Phyllantus niruri L.) Berbasis Teknik Spektrofotometri Inframerah Dan Kemometrik. IPB, Bogor.

Midun, 2012, Uji Efektivitas Ekstrak Lengkuas Merah (Alpinia purpurata K.) Dalam Menghambat Pertumbuhan Bakteri Stapphylococcus aureus Dan Bakteri Escherichia coli Dengan Metode Disc Diffussion

Redha, A. 2010, Flavonoid: Struktur, Sifat Antioksidatif dan Peranannya Dalam Sistem Biologis. Jurnal Belian Vol.9 No. 2 Sep: 196-202

Sarker SD, Latif Z, \& Gray AI, 2006, Natural products isolation. In: Sarker SD, Latif Z, \& Gray AI, editors. Natural Products Isolation. 2nd ed. Totowa (New Jersey). Humana Press Inc. hal. 6-10, 18.

WHO, 2011, Global Infection disease response: epidemic update and health sector progress toward universal access. Progress Report. 